\title{
Green growth: a game changer ushering in the death of the internal combustion engine?
}

\author{
G. Nhamo \\ Institute for Corporate Citizenship, \\ University of South Africa, South Africa
}

\begin{abstract}
The global movement promoting green growth transition is growing into one huge multi-dimensional game changer and evidence pointing to the death of the internal combustion engine (ICE) is growing. Green growth rests upon the need to convert economies from being resource-intensive to being low carbon and resourceefficient aimed at addressing, among key challenges, ecosystems decay, biodiversity loss, climate change, water stress, and energy security. To this end, the use of renewable energy as well as clean and energy efficient technologies is now inevitable. Among such clean and energy efficient technologies today are electric vehicles, especially battery electric vehicles and hydrogen fuel cell vehicles. Could green growth transition be a game changer offering multiple tipping points against the ICE? This is a question the paper addresses. The paper presents arguments that contribute to current global debates regarding the role of renewable energy as well as clean and energy efficient technology in green growth, especially in the transport sector. The paper conclusion is that, yes, if there is global scaling up, green growth signals the inevitable death of the ICE in the not so distant future.
\end{abstract}

Keywords: green growth, combustion engine, electric vehicles, game changer.

\section{Introduction}

Game changers embedding multiple tipping points get professionals and nonprofessionals talking and worried. Such phenomena bring along risks and opportunities in the economic, social, environmental and governance spaces of 
engagement. Over the decades, the world has witnessed game changers in the vehicle manufacturing sector with the internal combustion engine (ICE) having been one of the tipping points against steam engine and likewise, the lithium ion (Li-ion) battery is among multiple tipping points against the ICE. The ICE has been around for more than one and a half century. This probably makes the ICE one of the perfected and publicly accepted technologies of all time. However, the ICE is now being threatened by green growth transition ushering in battery electric vehicles (BEVs) and hydrogen fuel cell vehicles (HFCVs). The debate surrounding the promotion of electric vehicles, particularly those drawing from renewable energy sources emanates from the global challenge being experienced from greenhouse gas (GHG) emissions that cause climate change, of which the transport sector is a significant contributor.

Globally, the transport sector contributes on average $13.1 \%$ of total GHG emissions (Pollet et al. [1]). Other concerns from the transport sector include air pollution, oil depletion, energy security and population growth. With the global human population having reached seven billion people in 2011 and expected to reach nine billion by 2050 , more challenges related to population growth and climate change will be witnessed (Pollet et al. [1]). As a result, green growth that promotes migration from a development path littered with a resource intensive past to one that will be resource efficient, places the minimal use of fossil based fuels on the future development agenda.

This paper draws data from authentic online sources such as the Electric Drive Transport Association (EDTA) (http://electricdrive.org), the United Nations Framework Convention on Climate Change (UNFCCC) (www.unfcc.int), Nissan South Africa (http://www.nissan.co.za) and other secondary sources to present a policy story that global leaders are witnessing as a potential substitute of the ICE in the form of electric and other non-fossil fuel based vehicles. The intention is to challenge scholars from a multi, inter and trans-disciplinary perspective to generate more debate on the bold proposal that one day, in the near future the ICE will be an obsolete technology.

\section{The dirty internal combustion engine (ICE)}

Van Vliet et al. [2] reveal that more than $90 \%$ of the transport sector is powered by fossil fuels, mainly from the ICE. The ICE technology is not only confined to the transport sector but also extends to stationary ICE installations in mining, manufacturing and other sectors that use fossil fuel powered generators, mills and pumps. The energy flow of the combustion engine is presented in Figure 1.

Data retrieved from the UNFCCC website hosting National Communication reports indicate that transport contributes significant amounts of GHG emissions in many nations. For example, in India, 1994 figures reveal 11\% of total GHG emissions was from the transport sector, 18\% in Mexico (2002), 14\% in Australia (2007), 27\% in Canada (2007), 18.5\% in Japan (2007), and 13\% in South Africa (2000) UNFCCC [4]. 


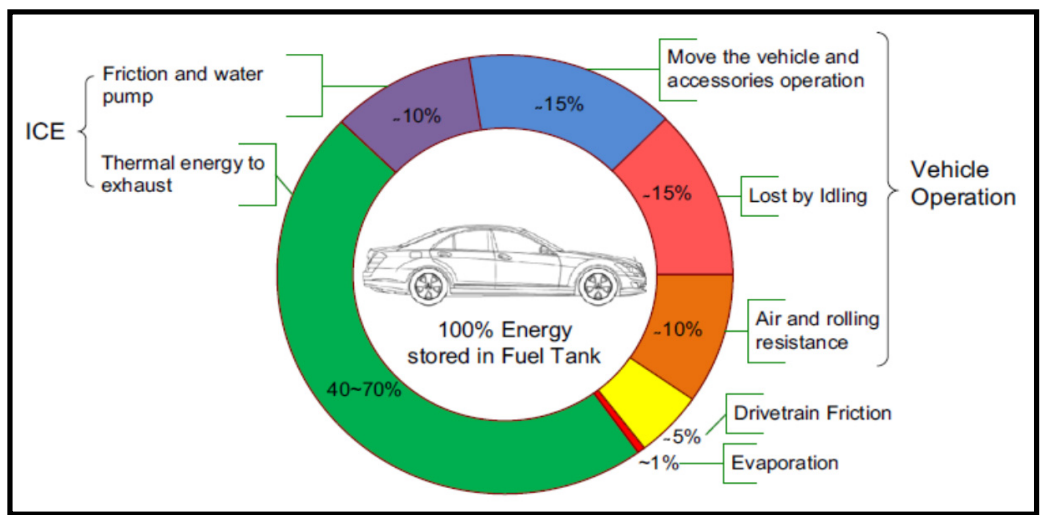

Figure 1: Typical energy flow of internal combustion engine vehicle. Source: Tie and Tan [3, p. 85].

\section{Emerging policy incentives}

A range of policy incentives have surfaced globally. Due to space limitations, only two policy reform regimes for the United States of America (USA) and China are discussed here. The two economies are the largest in the world. Furthermore, China and the USA are the world's $1^{\text {st }}$ and $2^{\text {nd }}$ highest GHG emitters. In the USA, there has been significant policy reform to accommodate the sale of electric vehicles. The Recovery Act USA Department of Energy [5] witnessed the government commit to building local manufacturing capacity for advanced Li-ion batteries, a critical element in the industry. The investments to build this capacity amounted to US\$2.4 billion in loans to Tennessee, Delaware and California factories. An additional US\$2 billion in grants was budgeted for 30 factories to produce the Li-ion batteries, motors and other components for electric vehicles USA Department of Energy [5]. To this end, the companies have been matching the government financial support dollar for dollar with the aim to have 50,000 Li-ion batteries manufactured annually as of December 2011 and 500,000 Li-ion batteries by December 2014. The Recovery Act further supports demonstration projects of 13,000 electric vehicles and over 22,000 charging points in over 20 cities in the USA. This venture further witnessed companies matching the funding dollar for dollar to the tune of $\$ 400$ million. Tax credits for buying electric vehicles were introduced ranging between $\$ 2,500$ and $\$ 7,500$ depending on the battery capacity.

Yang et al. [6] portray a late entry of China into the electric vehicle production platform with the country's designation of this technology as a key national programme in the 1990s. The electric vehicle policy reform and regulatory environment came in five distinctive areas, namely: national strategies for new energy vehicles in 2009 and 2012; national research programmes in 2001, 2006 and 2011; national subsidies of 2009/10 (10 cities 1,000 vehicles project), rules and regulations for manufacturing and products of 2009/10; and technology and emissions standards of 2007 and 2010. 


\section{About hybrid electric vehicles (HEVs), BEVs AND HFCVs}

Chan [7] provides a good historical account on HEVs, BEVs and HFEVs. Of the three sets of vehicles discussed, the HEV is one propelled by both the motor and ICE. In terms of major issues, BEVs have challenges with the battery and battery management, charging facilities and cost. The historical landmarks in BEVs development are shown in Figure 2. The HEVs present difficulties in multiple energy sources control, optimisation and management. They also have challenges with battery sizing and management. Lastly, the HFEVs' major drawback is the fuel cell costs, life cycle and reliability Chan [7]. There are also further challenges with infrastructure such as the installation charging stations.

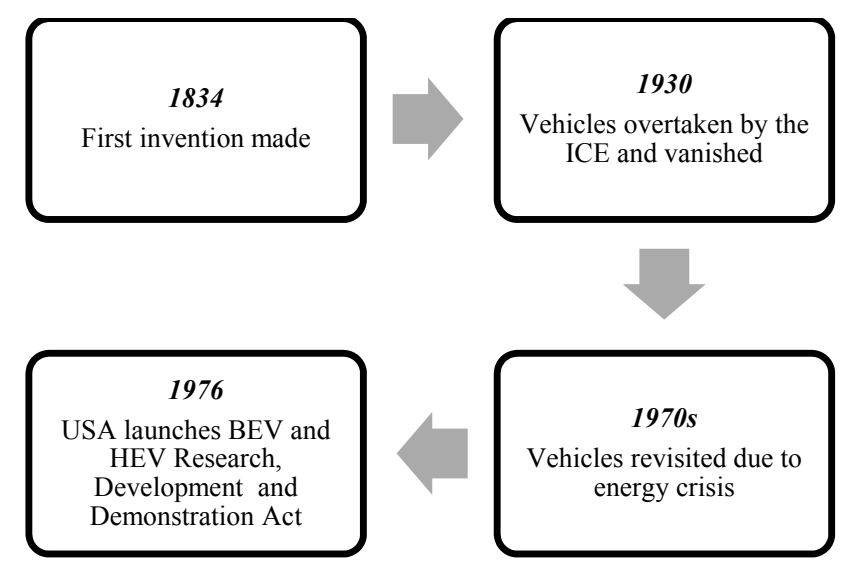

Figure 2: Historical landmarks in electric vehicles development. Source: author, based on Chan [7, p. 706-707].

As early as 2002, Lave and MacLean [8] compared environmental impacts of HEV against the ICE. They used the second generation Toyota Prius and the ICE Corolla. In their conclusion, "the more complicated and expensive Prius has lower pollutant and carbon dioxide emissions and better fuel economy than the Corolla" (Lave and MacLean [8, p. 155]). A study comparing HEV, BEV and hydrogen fuel cell vehicles (HFCV) was conducted by Granovskii et al. [9]. It emerged that the $\mathrm{BEV}$ was more environmentally friendly if the electricity comes from renewable energy sources. Overall, BEVs and HFCVs are known to have 'zero emissions' (or ultra-low emissions) and for being high in energy efficiency. The common modes of electric vehicles are presented in Table 1. Although all the electric vehicles play out as tipping points for the combustion engine, it is the BEV type that will really substitute the combustion engine if up scaled (Egbue and Long [10]).

On 25 January 2011, in his state of the Union Address, President Barack Obama proclaimed the wanted one million electric vehicles on American roads by 2015 to reduce dependence on oil and to take the lead in the growing electric vehicle 
manufacturing sector (Obama [11]). The proclamation was triggered by the fact that there were more plug and drive electric vehicles in China than the USA and anywhere in the world. Although not directly speaking to electric vehicles, in 2014, Obama followed up his 2011 address by announcing that he wanted fuel efficient trucks with 'tougher fuel efficiency standards for delivery vehicles' planned to be operational in March 2016 (Anderson [12]).

Table 1: Electric vehicles types.

\begin{tabular}{|l|l|l|}
\hline \multicolumn{1}{|c|}{ Vehicle type } & \multicolumn{1}{|c|}{ Description } & \multicolumn{1}{c|}{ Benefits } \\
\hline $\begin{array}{l}\text { Hybrid electric } \\
\text { vehicles (HEV) }\end{array}$ & $\begin{array}{l}\text { Electric vehicles that use an internal } \\
\text { combustion engine in addition to an } \\
\text { electric motor. }\end{array}$ & $\begin{array}{l}\text { Better fuel economy, less expensive } \\
\text { to run and lower emissions than } \\
\text { similar conventional vehicles. }\end{array}$ \\
\hline $\begin{array}{l}\text { Plug-in hybrid } \\
\text { electric vehicles } \\
\text { (PHEV) }\end{array}$ & $\begin{array}{l}\text { Electric vehicles with smaller internal } \\
\text { combustion engine and more powerful } \\
\text { electric batteries that can be } \\
\text { recharged. }\end{array}$ & $\begin{array}{l}\text { Better fuel economy, less expensive } \\
\text { to run and lower emissions than } \\
\text { similar HEVs and conventional } \\
\text { vehicles. Offers flexibility of fuel } \\
\text { source. }\end{array}$ \\
\hline $\begin{array}{l}\text { Battery electric } \\
\text { vehicles (BEV) }\end{array}$ & $\begin{array}{l}\text { Electric vehicles that derive motive } \\
\text { power exclusively from on board } \\
\text { electrical battery packs that can be } \\
\text { charged with a plug through an } \\
\text { electric outlet. }\end{array}$ & $\begin{array}{l}\text { No liquid fuels and zero emissions } \\
\text { at tailpipe. Less expensive to run } \\
\text { than similar HEVs and conventional } \\
\text { vehicles. }\end{array}$ \\
\hline
\end{tabular}

Source: Egbue and Long [10, p. 718].

\section{Electric vehicles uptake}

From its status quo report on the one million electric cars policy pronouncement by President Obama, the USA Department of Energy [5] revealed that although the policy statement goal was rather ambitious, the country's motor vehicle industry had the capacity to see 1.2 million electric cars on the roads by 2015 . From the USA perspective, capacity remained a major threat to attaining that goal. As discussed earlier, to counter this threat, Obama initiated programmes that included improvements on consumer tax credit, preparing cities for the increasing demand for the cars and increased support on research, innovation and development. Among the early entries into the electric vehicle market was the Nissan Leaf and Chevrolet Volt. The USA consumers seem to have responded well to the President's goal and trends in the Nissan Leaf (BEV) sales reflect this clearly (Figure 3). The growth in sales has been phenomenal, increasing from 67 units sold in in February 2011 to 1425 units sold in February 2014.

As of April 2013, the Nissan Leaf had reached a landmark of 62,000 units sold globally since its launch in December 2010 [14]. This figure makes the Nissan Leaf the most sought after 'zero emitting' electric car worldwide. The Nissan Leaf has also found its way into Africa with four such cars having been purchased by South Africa's Department of Environmental Affairs (DEA) making them the only 'zero carbon' emitting electric vehicle in Africa as of December 2013. Figure 4 shows one of the four Nissan Leafs owned by the DEA. The car can cover a distance of up to $200 \mathrm{~km}$ if fully charged Nissan Global [14] and a maximum speed of $150 \mathrm{~km}$ per hour. 


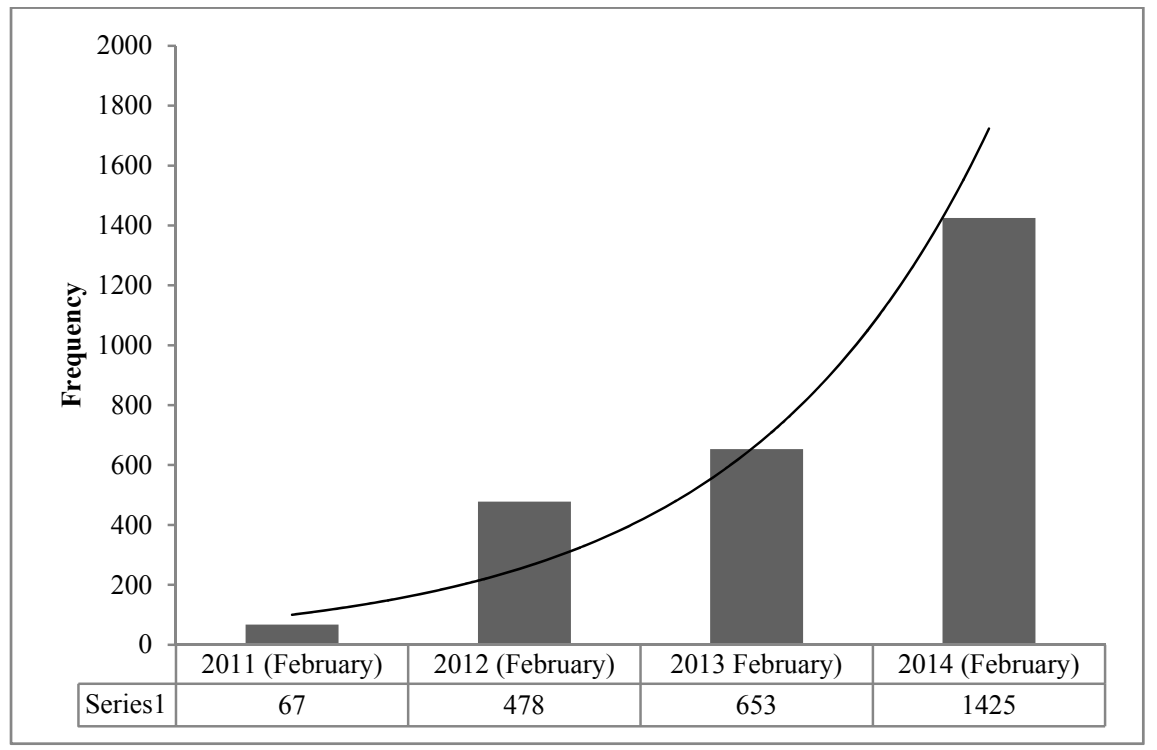

Figure 3: Nissan Leaf USA February month sales trends (2010-2014). Source: author, data from Voelcker [13].

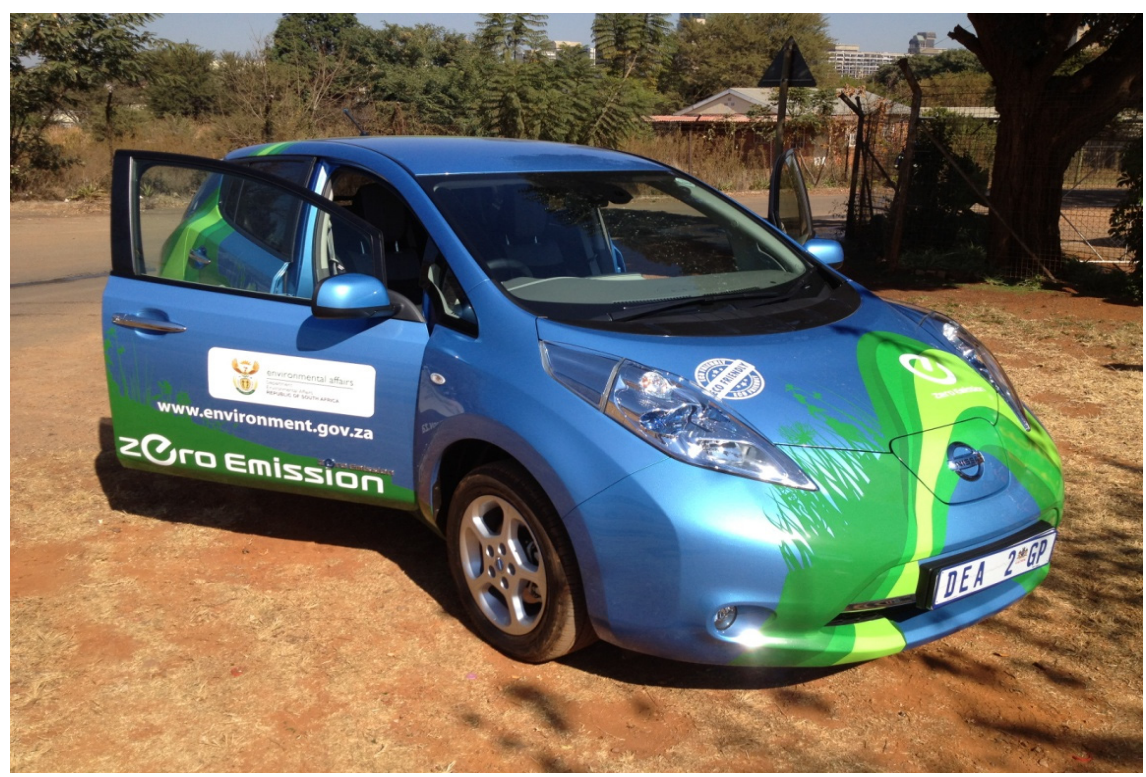

Figure 4: A Nissan Leaf from South Africa's DEA. Source: author. 
The Nissan Leaf has been recognised globally for its 'greenness' winning a number of awards that include: being named 2011 World Car of the Year at the New York International Auto Show Nissan Global [14]; winner of the 2012 RJC Car of the Year award in Japan from the Automotive Researchers' and Journalists' Conference of Japan (RJC); winning the 2011-2012 Japan Automotive Hall of Fame (JAHFA) Car of the Year; and 2011-2012 JAHFA Car Design of the Year awards from the selection committee of JAHFA Nissan Global [14]. The January 2014 Nissan Leaf European sales compared to other electric vehicles (HEVs) is shown in Figure 5. The Nissan Leaf outclasses all other electric vehicles even though it is a BEV rather than a HEV or HFCV. The Nissan Leaf's January 2014 sales figure for the USA, Japan and Europe stood at 3,736 units (Loveday [15]).

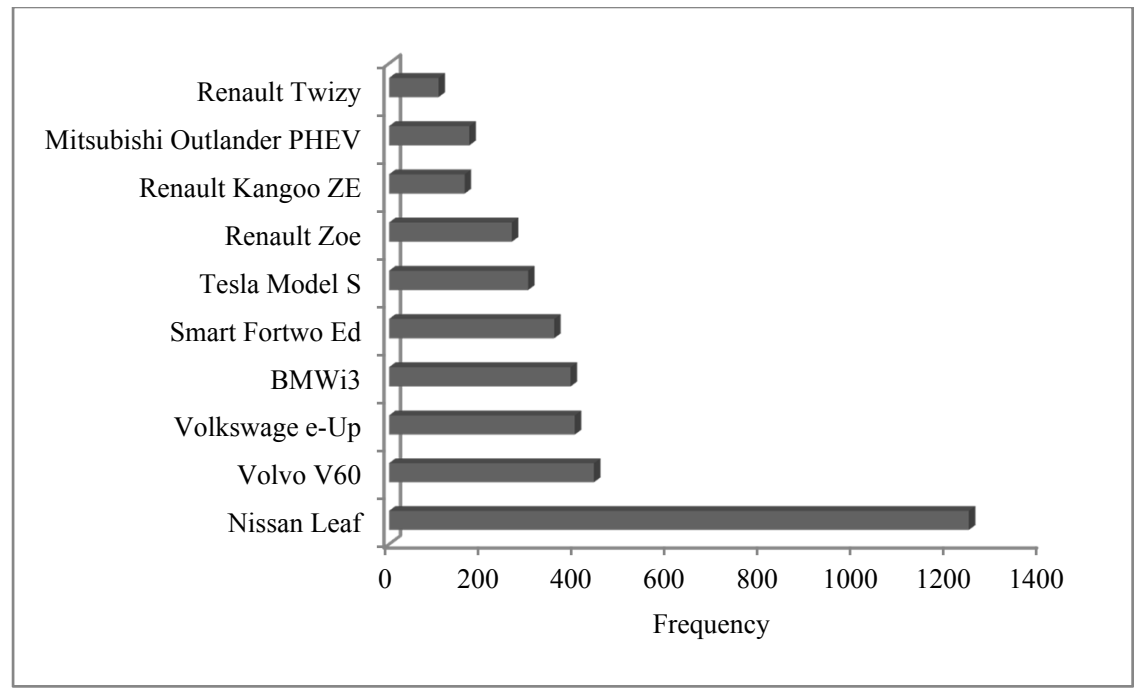

Figure 5: January electric vehicle sales in Europe. Source: author, data from Loveday [15].

News 24 [16] reported the excitement of the Nissan-Renault CEO after concluding a national deal to supply ALL government departments with battery powered vehicles in the Himalayan kingdom of Bhutan. During the signing ceremony, the Nissan-Renault CEO announced the desire to have 1.5 million units sold globally by 2020 . The CEO further indicated that the Nissan Leaf sales had gone past 100,000 units globally and the demand was pointing to over 60,000 units annually as from 2014. The Renault Zoe (an HEV) was further highlighted as making good progress on the market, although the exact sales figures were not released. 


\section{Barriers to electric vehicles uptake and scaling up}

Despite their 'greenness', electric vehicles' uptake face a number of barriers (Egbue and Long [10]). A key challenge is that consumers tend to be reluctant to take up technology that is novel and unproven. Among the highlighted concerns from consumers regarding electric vehicles are: battery range (distance travelled by the car before re-charging), battery size and weight, high purchase price (cost), charging infrastructure and duration, reliability and safety. I could add from my side, fear of accident damage and the local capability and to maintain such cars.

Other challenges may include financing and insurance as new technology presents risks. The USA data on electric and total vehicle sales reveal the challenge in scaling up sales in electric vehicles and the potential to close the gap (Figure 6).

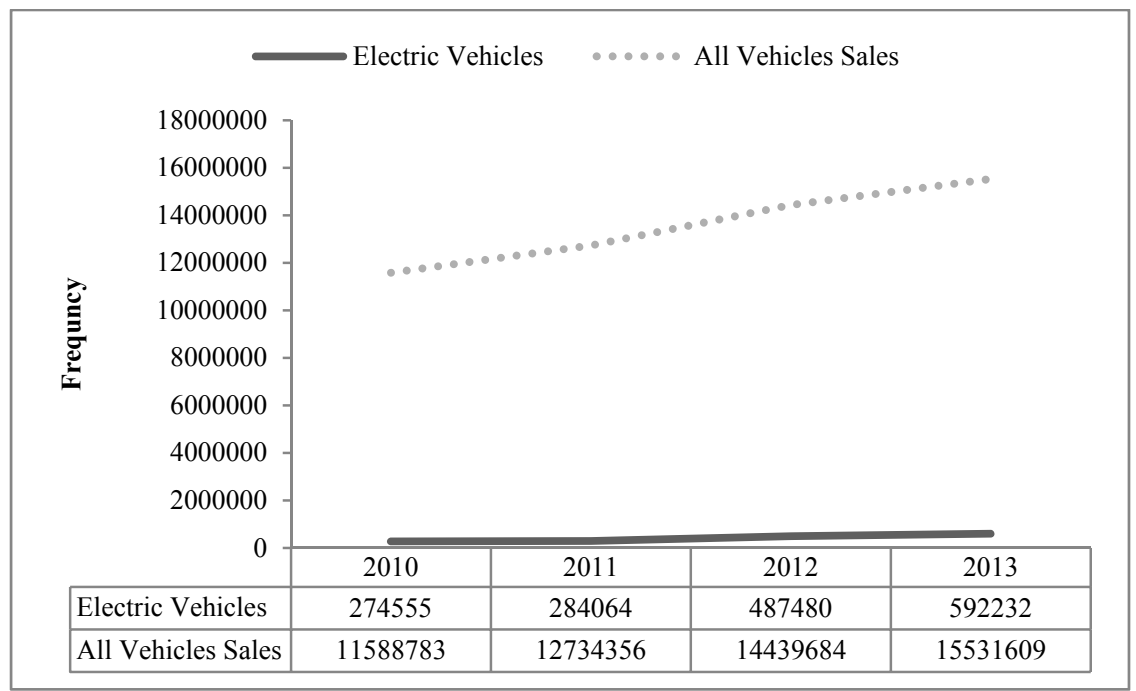

Figure 6: Vehicle sales in the USA (2010-2013). Source: author, data from EDTA [17].

Although there remains a huge gap in sales between electric and ICE vehicles, the general sales for electric vehicles reveal an upward trend (Figure 7). Another challenge relate to the cost of operating these vehicles. Lee and Lovellette [18] found out that as of 2010, the purchase and operation costs of a HEV and a BEV was $\$ 5,377$ and $\$ 4,819$ more expensive compared to the ICE respectively. However, modelling on pricing showed that between 2020 and 2030 BEVs could be cheaper by between $\$ 1,115$ to $\$ 7,181$ if battery costs decrease and petroleum prices increase. Pollet et al. [1] concur that cost is probably the key factor for public acceptance and uptake of the cars. The authors reveal that as of 2012, a Li-ion battery with $35 \mathrm{kWh}$ storage capacity cost about $\$ 30,000$ to produce. 


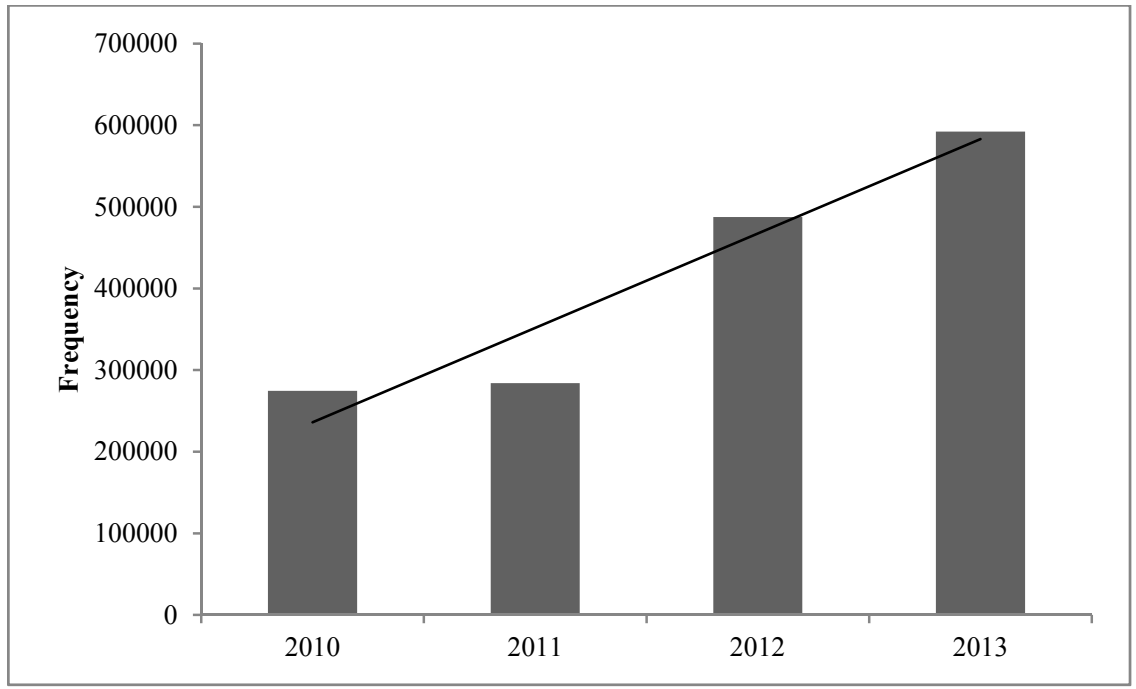

Figure 7: Electric vehicle sales in the USA (2010-2013). Source: author, data from EDTA [17].

However, according to the authors, Toyota has been making advances in this space and has managed to cut the cost of producing its fuel cell vehicles by $90 \%$ since 2005 from about $\$ 1$ million per unit to $\$ 100,000$. Even then this cost is way too high compared to a mere $\$ 1,000$ of producing the conventional ICE of similar functionality. From Pollet et al. [1] work, the public acceptable price for a HFCV is about $\$ 50,000$ for a luxury sedan and this is within reach. The price reach for the BEVs of about $\$ 40,000$ has been attained and it is expected to go down to between $\$ 20,000$ and $\$ 30,000$ by 2020 .

The cost issue is more pronounced in developing countries where citizens do not have the luxury of having savings. In South Africa (and many other African countries), what citizens require is to have at least a car. In this regard, the electric vehicles, particularly the popular brand Nissan Leaf may not be within many citizens' reach. The Leaf, for example (Nissan South Africa [19] was retailing about US\$42,000 (Exchange rate of $\$ 1=\mathrm{R} 10.7$ ) in March 2014 compared to a higher range new Nissan Sentra at almost half the price (US\$24,000). Price comparison of the Leaf with selected ICE Nissan brands is shown in Figure 8. The Micra, which is very close to the Leaf in terms of shape and size is about a third in terms of pricing. Surprisingly, the Leaf price compares favourably with popular ICE Nissan SUVs like the X-Trail and Pathfinder. In Africa, many black citizens have two homes - one in town and the other in the rural areas where current small BEVs may not be able to manoeuvre. In addition, faced with a choice to buy a Nissan Leaf at equivalent price for a Pathfinder or X-train, African consumers may be biased towards a bigger car for reason mentioned here regarding the state of African and other developing countries roads. 


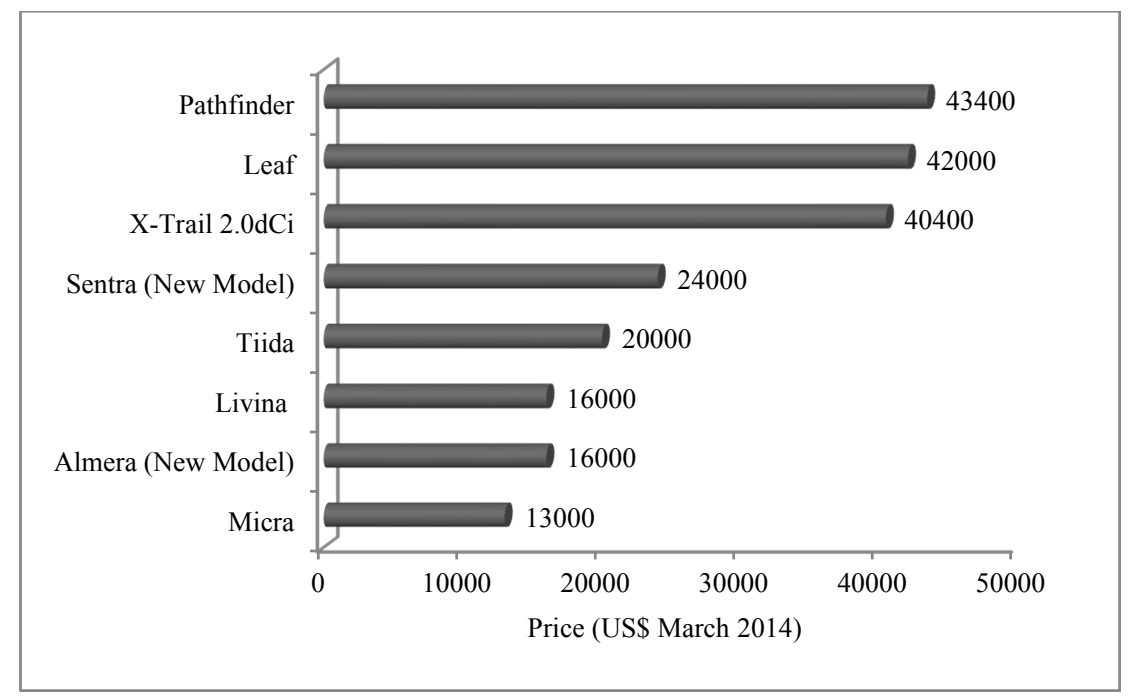

Figure 8: Leaf pricing versus selected Nissan brands in South Africa. Source: author, data from Nissan South Africa [19].

After discussing the key message from this paper with my 11 year old son, Anesu Tadiwanashe Nhamo on picking him up from school in Pretoria, South Africa (7 March 2014), the boy was direct. "It will be difficult to abandon the combustion engine. What happens to Formula One as these electric cars do not have the necessary speed? Will the sport be abandoned?" This was a cool thinking for his age. This also sent me thinking. He further spoke about the battery capacity to store enough power to complete the race at such high speeds. True, there are challenges for the battery technology here.

The issue of job losses may not be overemphasised. Ditching the ICE means the whole world must search alternative employment opportunities in the value chain. One only needs to think of those employed (to support their family and society's livelihoods) in the value chain covering radiator manufacturing, carburetors or direct injection systems, flywheel, crankshafts and casing, timing chains, oils, fuels (including Sasol's synthetic technology for coal), manifolds, fuel lines and tanks, gaskets, cylinders, pistons, engine blocks, injectors and oil rings, valves and valve seals, engine heads, springs, plugs, the value chain list goes on. The bigger question comes: will the BEVs have the same functionality regarding jobs including repairs (mechanical, electrical and panel beating)? The same story is shared with other economic sectors with ICE based equipment like in agriculture, mining, tourism etc. Jobs are not only a social and economic issue, they are also politically charged. 


\section{Key messages in favour of scaling up}

In as much as the exact period of scaling up the uptake of, especially, BEVs, is not known, this paper wish to present some of the key tipping points against the ICE. With regard to cost, there have been significant reductions already including those highlighted by Toyota. During the launch of the Nissan Leaf in South Africa in October 2013, Managing Director for Nissan South Africa, Mike Whitfield highlighted that "the Leaf's sales price of R446,000 might seem costly. However, if one includes electricity costs of about R22,500 over a six-year period and maintenance costs of $\mathrm{R} 1,500$, the total cost of the car over the six-year period (R470,000) compares favourably to the total cost of ownership of equivalent petrol (R484,000) or hybrid (R505,000) models over the same period" (Lamprecht [20]).

The political will to come up with new generation green procurement policies and regulations is picking momentum and this can fast tract the tipping points. In addition, ( $\operatorname{tax}$ ) incentives and disincentives will have a huge role to play, including subsidies for consumers who buy BEVs and exemptions, for example, from carbon taxes, fuel levies and e-Toll fees in countries that have such. Superpower political buy in will be fundamental. For example, countries like the USA may be driving a BEV agenda to scale down their dependence on powerful oil rich trading blocks. Some of these oil rich countries are viewed as undemocratic. Furthermore, quick advancement in the BEV and similar breakthroughs will reconfirm the fading supremacy of countries like the USA. Lastly, the ever rising oil prices are good enough an incentive for BEVs' continued research and development.

\section{Conclusion}

Given the forgone, it emerges that although there are challenges associated with scaling up the production and sale of low carbon emitting vehicles that include $\mathrm{HEV}$, BEVs and HFCVs, there has been significant breakthroughs. The Nissan Leaf (a BEV) has managed to sale over a 100,000 units since it broke to the market in 2010. Indications are that up to 50,000 units could be sold annually moving forward. Toyota on the other hand has been making significant progress with the HFCVs technology mainly aimed at reducing the cost of these vehicles to the publicly acceptable price of $\$ 50,000$. Given this trend the question remains: Is green growth transition a game changer leading to the death of the ICE? The answer is: a qualified yes. There are indicators to this effect. What makes the BEVs a game changer is the fact that it is no longer Nissan (Leaf) alone on this front, but all major car manufacturers have joined in the green cars race. This is likely to have the cumulative impacts as each major car manufacturer's entry into the BEVs race is a mini-tipping point towards the death of the ICE. The role of green consumers (including the emerging green political parties) and environmentally conscious CEOs will further play a key role. Let us continue having this conversation! 


\section{References}

[1] Pollet, B.G., Staffell, I and Shangc, J.L. (2012). Current status of hybrid, battery and fuel cell electric vehicles: From electrochemistry to market prospects.

[2] Van Vliet, O.P.R., Kruithof, T., Turkenburg, W.C., and Faaij, A.P.C. (2010). Techno-economic comparison of series hybrid, plug-in hybrid, fuel cell and regular cars. Journal of Power Sources 195: 6570-6585.

[3] Tie, S.F. and Tan, C.W. (2013). A review of energy sources and energy management system in electric vehicles. Renewable and Sustainable Energy Reviews 20: 82-102.

[4] UNFCCC (2014). National Communications. Available at: http://unfccc.int/essential_background/library/items/3599.php?such=j\&sy mbol=/COM\#beg. Accessed 5 March 2014.

[5] USA Department of Energy (2011). One million electric vehicles by 2015: February 2011 status report. Washington DC: USA Department of Energy.

[6] Yang., L., Xu, J. and Neuhäusler, P. (2013). Electric vehicle technology in China: An exploratory patent analysis. World Patent Information 35: 305-312.

[7] Chan, C.C. (2007). The State of the Art of Electric, Hybrid, and Fuel Cell Vehicles. Proceedings of the IEEE. 95 (4): 704-718.

[8] Lave, L.B. and MacLean. H.L. (2002). An environmental-economic evaluation of hybrid electric vehicles: Toyota's Prius vs its conventional internal combustion engine Corolla. Transportation Research Part D. 7: $155-162$.

[9] Granovskii, M., Dincer, I. and Rosen, M.A. (2006). Economic and environmental comparison of conventional, hybrid, electric and hydrogen fuel cell vehicles. Journal of Power Sources 159: 1186-1193.

[10] Egbue, O. and Long, S. (2012). Barriers to widespread adoption of electric vehicles: An analysis of consumer attitudes and perceptions. Energy Policy 48: 717-729.

[11] Obama, B. (2011). Sate of the Union address. Available online at: http://stateoftheunionaddress.org/2011-barack-obama. Accessed, 4 March 2014.

[12] Anderson, A. (2014). Obama wants more fuel-efficient trucks on US roads. Available online at: http://www.environmental-expert.com/. Accessed 2 March 2014).

[13] Voelcker, J. (2014). Plug-In Electric Car Sales for Feb: Leaf Up, Volt Down (Tesla Unknown As Usual) - Final Update. Available online at: http://www.greencarreports.com/news/1090645_plug-in-electric-car-salesfor-feb-leaf-record. Accessed on 6 March 2014.

[14] Nissan Global. (2013). Electric Vehicles (EV), available at: http://www.nissan-global.com/EN/ENVIRONMENT/CAR/FUEL_ BATTERY/DEVELOPMENT/EV/. Accessed 21 February 2014. 
[15] Loveday, E. (2014). Plug-In Electric Vehicle Sales in Europe - January 2014. Available online at: http://insideevs.com/plug-in-electric-vehiclesales-in-europe-january-2014/. Accessed 3 March 2014.

[16] News 24 (2014). Nissan boss upbeat about green car future. Available online at: http://www.news24.com/Green/News/Nissan-boss-upbeat-aboutgreen-car-future-20140221. Accessed 1 March 2014.

[17] EDTA (Electric Drive Transport association). Electric Drive Sales Dashboard. Available online at: http://electricdrive.org/index.php?ht $=\mathrm{d} / \mathrm{sp} / \mathrm{i} / 20952 / \mathrm{pid} / 20952$. Accessed 6 March 2014.

[18] Lee and Lovellette, G. (2011). Will Electric Cars Transform The U.S. Vehicle Market? An Analysis of the Key Determinants. Harvard: Harvard Kennedy School.

[19] Nissan South Africa (2014). All vehicles. Available at: http://www.nissan.co.za. Accessed 07/032014.

[20] Lamprecht, I. (2013). Nissan Leaf hits market despite absence of government incentives. Available online at: http://www.moneyweb.co.za/ moneyweb-south-africa/sas-first-electric-car-goes-on-sale. Accessed 7 March 2014). 